УДК 340.15

DOI https://doi.org/10.32837/apdp.v0i85.1858

O. В. Лесик

\title{
РОЗВИТОК ЗЕМЕЛЬНИХ ПРАВОВІДНОСИН У ЗАХІДНО-УКРАЇНСЬКІЙ НАРОДНІЙ РЕСПУБЛІЦІ (1918-1919 РР.)
}

У сучасних умовах в Україні відбувається активне реформування правового регулювання земельних відносин, яке спрямоване на забезпечення раціонального й ефективного використання земельних ресурсів. Зазначене реформування земельного законодавства України не можливе без вивчення і врахування історичного досвіду становлення й розвитку правового регулювання земельних відносин на українських землях від найдавніших часів і до сьогодні. У зв'язку з цим особливий інтерес викликає історико-правовий аналіз розвитку земельних правовідносин в Західно-Українській Народній Республіці (1918-1919рр.).

В жовтні-листопаді 1918 р. Австро-Угорська монархія фактично припинила існувати, а на їі руїнах виникли нові національні держави, з-поміж яких і Західно-Українська Народна Республіка (далі - ЗУНР). У Львові 18 жовтня 1918 р. українські посли до австрійського парламенту створили Українську Національну Раду (УНРаду) - представницький орган українців Галичини, Буковини і Закарпаття (очолив адвокат Євген Петрушевич), яка поставила питання про об'єднання всіх західноукраїнських земель і утворення єдиної Української держави.

Після того, як у Львові стало відомо про приїзд до міста Польської ліквідаційної комісії, створеної напередодні у Кракові, яка мала перебрати від австрійського намісника Карла фон Гуйна владу над краєм і включити його до складу Польщі, було вирішено встановити контроль над регіоном. Тому 1 листопада 1918 р. українські військові формування на чолі з сотником Дмитром Вітовським встановили контроль над найважливішими стратегічними об'єктами Львова та Східної Галичини [7, с. 5]. Ця подія увійшла в історію як «листопадовий чин». Польська сторона не змирилася із втратою українських територій і розпочала бойові дії з метою відвоювання Східної Галичини.

В умовах польсько-української війни УНРада заходилася розбудовувати державно-правові інституції. У програмному маніфесті УНРади 5 листопада 1918 р. було задекларовано загальне виборче право, рівність всіх громадян перед законом, 8-годинний робочий день, соціальний захист потребуючих, охорону праці та проведення аграрної реформи: «Український парламент, що вибереться і збереться зараз, як тільки край успокоїться, переведе справедливу аграрну реформу, силою котрої земля великих земельних дібр перейде на власність малоземельних і безземельних» [13, с. 1]. УНРада декларувала створення у майбутньому ситуації, коли не буде «панування багатших та економічно сильніших над бідними й економічно слабшими» [8, с. 336].

У наступні дні відбулося уконституювання нової держави: 9 листопада 1918 р. створено уряд - Державний Секретаріат, який очолив авторитетний у краї правник 
Кость Левицький. Уряд ЗУНР складався з 14-ти секретаріатів, один із яких - земельних справ - очолив Степан Баран. Дотичним до сфери сільського господарства був і так званий Український харчовий уряд на чолі зі Степаном Федаком, який налагодив співпрацю з відновленим товариством Сільський господар, українськими кооперативами та фінансовими організаціями [7, с. 6].

Міністр земельних справ С. Баран (1879-1953) - галицький громадський діяч і правник, член Української Національно-демократичної партії, розумів важливість вирішення аграрного питання. Він зазначав, що «в кожного народу й кожної держави найважнішою, справді життєвою справою є земельна справа. Чи радше справа землеволодіння. $Є$ правдою, що хто має землю і право нею користуватися, цей має запевнену майбутність» $[1$, с. 3]. С. Баран схилявся до думки, що збільшення селянського землеволодіння за рахунок земель поміщиків і церкви повинне здійснюватися крок за кроком і за відповідно встановлену плату [12, с. 233].

Безпосередньо аграрною реформою в ЗУНР мав займатися Секретаріат земельних справ, покликаний підготувати земельний закон. У повітах створювалися спеціальні земельні референти, які повинні були у найкоротший час формувати земельні відділи. До настання моменту початку поділу землі нею мала управляти обласна, повітові та громадські (по селах) комісії. До компетенції обласної комісії належало право конфіскації, відшкодування і перерозподілу землі. Повітова комісія була покликана стежити за використанням землі, реагувати на земельні скарги мешканців конкретного повіту. Громадська рада безпосередньо займалася управлінням на місцях і складалася із шести обраних представників громади та призначуваним за посадою голови - гмміни (громади) [18, с. 116].

13 листопада 1918 р. юридично було проголошено Західно-Українську Народну Республіку (ЗУНР), президентом якої став Свген Петрушевич. До скликання Установчих зборів ЗУНР керівництво державою покладалося на УНРаду і Державний секретаріат. У «Тимчасовому основному законі про державну самостійність українських земель бувшої австро-угорської монархії, ухваленому Українською Національною Радою на засіданні дня 13. Падолиста 1918» йшлося: «Держава, проголошена на підставі права самовизначення народів Українською Національною Радою у Львові дня 19. Жовтня 1918 року, обнимаюча весь простір бувшої австро-угорської монархії, заселений переважно Українцями, має назву Західно-Українська Народня Республіка» (стаття 1) [4, с. 473].

Формально ЗУНР проіснувала до 22 січня 1919 р., коли внаслідок Акту злуки об’єдналася з УНР і перетворилася на Західну Область УНР (ЗОУНР). Втім, фактично у правовому полі ЗУНР залишалася незалежним політичним утворенням аж до липня 1919 р., коли її військо - Українська Галицька Армія (УГА) під тиском польських збройних формувань, підсилених сформованою у Франції стотисячною армією Юзефа Галлера, перетнули р. Збруч, яка слугувала природним кордоном із Наддніпрянською Україною [3, с. 141]. В період із листопада 1918 до липня 1919 рр. творення Української державності в Галичині відбувалося в мінімальній кореляції з тим, що відбувалося по другий бік Збруча (винятком може слугувати хіба що дещо тісніша військова співпраця урядів двох українських республік). 
Після набуття чинності Акту про злуку УНР і ЗУНР в політичних колах останньої обговорювався Закон про землю від 8 січня 1919 р., прийнятий Директорією УНР. Як і слід було очікувати, представники ЗУНР не надто прихильно поставилися до його положень, здебільшого через запропоновану соціалізацію землі під впливом лівих політичних партій. Генеральний секретаріат УНР в офіційному роз'ясненні звертав увагу на те, що «скасування приватної власності на землю й перехід іï до трудового народу слід розуміти так: право власності на ці землі переходить до народу Української Республіки» [2].

Земельний закон УНР 1919 р., що складався із трьох розділів і 33-х параграфів, скасовував приватну власність на землю (включно з надрами) й усуспільнював іiі. Право користування землею мали всі громадяни незалежно від віросповідання, статі чи національності. За користування землею не знімалася плата. Колишнім власникам заборонялося продавати, купувати, закладати, дарувати чи передавати будь-кому землю, оскільки вона була визнана такою, що належить не конкретній інституції чи особі, а всьому народові. Цим можна пояснити продовження роботи над окремим земельним законом всередині ЗУНР. Більше того, делегація галицьких селян, очолюваних Теофілом Старухом, відвідавши Київ, клопотала про узаконення приватної власності й наділення землею тих, хто її обробляв на території Галичини [18, с. 110].

У правовій сфері керівництво ЗУНР задекларувало незмінність колишніх австрійських законів, але в тому обсязі, в якому вони не суперечили правовим принципам існування нової держави. Наприклад, «Закон про тимчасову організацію судів і власти судейської» від 21 листопада 1918 р. гласив (стиль викладу збережено): «Закони і розпорядки, на підставі котрих в бувшій австрійській державі виконувано судівництво, оскільки вони не противляться державности Західно-Української Народньої Республіки остають аж до їх заміни, зглядно знесення, в правній силі і на їх підставі має ся дальше вести судівництво» (Стаття 1) [4, с. 474]. Якщо із принципами австрійського судочинства західноукраїнська влада на загал погоджувалася, то система земельних правовідносин не задовольняла населення краю, більшість якого становили мало- чи безземельні селяни-українці.

Утворення ЗУНР давало галицьким українцям підстави сподіватися на реформування земельних правовідносин і вирішення аграрного питання, оскільки селяни перебували в складному економічному становищі. Це цілком розуміла і нова влада, фокусуючи увагу на реорганізації господарства. Під час сесії УНРади у Станіславові (Івано-Франківську) на початку січня 1919 р. була створена земельна комісія, до складу якої ввійшли представники основних політичних партій Галичини, а також фахівці з права [12, с. 234]. Тоді ж державним секретарем земельних справ став Михайло Мартинець, у підпорядкуванні якого перебували рільничі референти в повітах ЗУНР. При повітах створювалися окремі земельні відділи так звані «уряди». Крім «урядів» формувалися спеціальні земельні комісії, яким підпорядковувалися сільські рільничі комісії. Секретаріат у земельних справах також контролював лісове й водне господарство [7, с. 185].

30 січня 1919 р. на засіданні Секретаріату земельних справ було створено спеціальну комісію на чолі з Т. Мартинцем. Ця комісія, яка складалася з 15-ти фахівців, 
обговорила земельний закон УНР і дійшла висновку, що він суперечить місцевим традиціям. На мою думку, уряд ЗУНР вдало скористався важливим юридичним моментом - Земельний закон УНР був ухвалений до підписання Акту про злуку двох держав, тому міг вважатися необов'язковим для виконання. Такої думки, зокрема, дотримувався віце-президент УНРади, юрист Лев Бачинський [19, с. 286].

Під час наради галицьких юристів 30 січня 1919 р. у Станіславові щодо питання «Чи Земельний закон Директорії УНР є обов'язковим для ЗУНР?» її учасники зійшлися на думці, що земельна справа має бути в компетенції влади ЗУНР [7, с. 238]. При тому зауважу, що до підготовки земельної реформи в ЗУНР долучилися державні діячі УНР, зокрема автор Закону про землю в УНР Микита Шаповал. Основні принципи майбутньої реформи полягали у: 1) вивласненні більшої частини посілості через викуп; 2) визнанні приватної власності; 3) встановленні чіткого мінімуму земельних ділянок; 4) обмеженні права на спадок; 5) одержавленні лісів; 6) гарантуванні права безземельних і малоземельних на набуття землі; 7) впровадженні системи кредитування [9, с. 181].

У тлумаченні ключових понять земельного законодавства галицькі юристи послуговувалися австрійськими визначеннями. Так, австрійське право передбачало, що вивласнення наступало після: 1) проведення відповідної процедури, передбаченої законом; 2) відшкодування вивласненого. Не вважалися вивласненням випадки, коли патент дозволяв владі порушувати приватну власність без формальних гарантій. Наприклад, з юридичної точки зору не вважалося вивласненням порушення меж земельних ділянок під час копання ровів з метою затримання повені або ж копання окопів під час бойових дій [15, с. 211].

Інший приклад - питання спадку, зокрема земельного. Його в Австрійській імперії регулював Цивільний кодекс 1811 р., який визначав, що у випадку смерті особи, яка не залишила жодного передсмертного розпорядження, маєток переходив найближчому кровному родичу. Лінії споріднення виглядали так: перша діти (якщо було декілька дітей, то спадок ділився порівну); друга - батько і мати; третя - діди і баби і так далі (всього шість ліній).

Імператорський патент визначав, що селянські господарства мали спадковим порядком переходити без поділу у власність найстаршого сина (ні на внуків, ні на правнуків ця норма не поширювалася). Згідно з положеннями Цивільного кодексу у спадковому праві був закріплений принцип універсальності спадку - прийняття не тільки вигод, але й існуючих обтяжень [21, с. 93]. Спадкові права могли базуватися на законі, на договорі, на заповіті. Заповіт допускався як у письмовій, так і в усній формі. На змісті заповіту не встановлювалися значні обмеження, якщо тільки не йшлося про особливі земельні маєтки (наприклад, з особливим державним статусом. Коли ж у спадок передавалася земельна ділянка, законодавство вимагало внесення відповідного запису до грунтової книги $(\S \S 431,433)$ [21, с. 56].

Ще одним дуже важливим принципом, прописаним у січні 1919 р. земельною комісією, був принцип кредитування при купівлі земельної ділянки. Внаслідок ухвалення в Австро-Угорщині в 1868 р. Закону про кредит уможливлювалося лихварство, і багато селянської землі стало предметом спекуляції. Нерідко, щоб віддати взяті у кредит гроші, селянам доводилося виїздити на заробітки в інші країни 
(США, Канада, Аргентина, Бразилія) [10, с. 10]. Тож це питання вимагало значного корегування вже в новому державному утворенні, аби захистити українського селянина.

До Першої світової війни питаннями кредитування займалися Галицький акціонерний іпотечний банк у Львові (працював здебільшого із великими землевласниками), Галицький селянський кредитний заклад (так званий Рустикальний, або Селянський банк). У 1881 р. було створено Аграрний банк у Львові, метою якого було посередництво при закупівлі і продажу: 1) сільськогосподарських продуктів; 2) земельних ділянок (також конверсія іпотечних позик); 3) машин і сільськогосподарської техніки.

В 1883 р. засновано «Крайовий банк королівства Галичини і Володимерії з Великим князівством Краківським у Львові» для кредитування підприємств сільського господарства, промисловості і торгівлі. Він надавав під застави кредити для сільськогосподарських підприємств, громадам та окремим приватним особам. 31894 р. почали виникати українські кредитні товариства. За три роки їх уже було 11: «Віра» у Перемишлі, «Задаткова каса» у Стрию, «Зв’язковий банк» у Станіславові, «Надія» в Бережанах, «Поміч» у Теребовлі, «Дністер» у Львові, «Самопоміч» у Коломиї, «Руська каса» в Чернівцях, «Захист землі» у Львові, «Поміч» у Городку. Діяльність цих товариств сприяла розвиткові товарно-грошових відносин на селі.

В 1907 р. у Львові створено «Парцеляційне товариство «Земля», метою якого було об'єднання економічних сил своїх членів для забезпечення росту прибутків. Займався наданням кредитів своїм членам для придбання земельних ділянок, винаймання знарядь праці. В 1924 р. товариство змінило назву на Кооперативний банк «Земля». Кредитуванням дрібних землевласників займався Акціонерний земельний іпотечний банк, заснований 1910 р. у Львові (директор О. Кульчицький). Банк діяв на території Галичини і Буковини, мав філію у Станіславові. До 1914 р. банк видав українським селянам 1840 позичок на загальну суму 7070000 корон [6, с. 783]. Тож галицькі селяни могли покладатися на допомогу українських кредитних товариств в нових умовах - існування ЗУНР.

Фактично, аграрна реформа в ЗУНР розпочалася з ухвалення 18 березня $1919 \mathrm{p}$. Закону «Про вивласнення великих табулярних посілостей», який встановлював порядок конфіскації земель у великих землевласників [2]. Табулярні посілості це землі, зареєстровані у спеціальних грунтових книгах (інтабуляція (intabulacje, intabulation) - спосіб набуття права на нерухоме майно, в тому числі й на землю). Запис до грунтової книги зумовлював такі правові наслідки: новий власник отримував право вступати у законне посідання грунтом - табулярне посідання (rechte gewere), що тягло за собою розпорядження землею, зокрема обтяження іпотекою; хто отримував власність на нерухомість, той отримував і права на неї (§ 442) [21, с. 59].

Паралельно з процедурою вивласнення Державний секретаріат впровадив монополію на продаж зерна і хліба, худоби. Селянську реформу мав провести майбутній парламент, розподіливши землю за рекомендацією УНРади на користь малоземельних і безземельних. Заступник державного секретаря закордонних справ ЗУНР М. Лозинський визначав аграрну реформу ключовим кроком у діяльності західноукраїнського уряду. Дипломат пропонував з великого землеволодіння сфор- 
мувати земельний фонд ЗУНР, з якого наділяти селян. Як керувати цим фондом, мали вирішити Установчі збори. Ця теза згодом стала ключовою у визначенні засад реформування сільського господарювання ЗУНР.

3 метою підготовки аграрного законопроекту на початку 1919 р. УНРада створила спеціальну земельну комісію, до складу якої увійшли І. Макух, С. Вітик, С. Данилович, Т. Старух та низка інших компетентних осіб. Оскільки розробка такого документа вимагала певного часу, комісія видала декілька резолюцій, які регулювали й процедуру оренди та проведення весняно-польових робіт [18, с. 108].

У питанні визначення механізму оренди відчувався вплив австрійського права. Орендар і орендодавець зобов'язувалися передати земельну ділянку в такому стані, що дозволяє її використання, не перешкоджає йому. Якщо предмет найму (земельна ділянка) мав певні недоліки, що перешкоджало його використанню, орендатор звільнявся від сплати на час полагодження тих недоліків. Орендар мав право здавати землю в суборенду, якщо не існувало ніякого застереження. Сплата за найм землі могла бути скасована (переглянута) за умови, коли орендованою ділянкою не можна було користуватися внаслідок пошкодження бурею, вогнем, повінню [15, с. 254].

10 лютого 1919 р. в склад земельної комісії було введено нових фахівців і таким чином розширено іï до 25-х осіб. Серед них -14 селян, п'ятеро юристів, троє священиків, двоє вчителів і один інженер. Замість І. Макуха головою комісії обрали Лева Бачинського - заступника голови УНРади [13, с. 3]. Л. Бачинський був відомим у Галичині адвокатом, провідником Української радикальної партії, в свій час обирався послом до австрійського парламенту. Він також увійшов в історію як один із творців Акту Злуки УНР і ЗУНР.

21 лютого 1919 р. Державний секретаріат ухвалив постанову про примусовий обробіток придатної для культивування сільськогосподарських рослин землі: «Всі грунти, пригожі для рільничої культури мають бути управлені і нікому не вільно лишати придатного до культури грунту облогом» [14]. Земельні власники й орендарі зобов'язувалися до 10 березня повідомити сільські земельні комісії, якщо вони були не в змозі (чи не бажали) обробити свої грунти й подати детальний опис ділянок.

Коли землевласник до кінця квітня 1919 р. не засіяв землі з його ж вини, то підлягав штрафові. Дані про засівання мала збирати рільнича комісія в кожній громаді, яка складалася з 4-х осіб. У випадку, коли власник не обробляв грунту і не повідомив про це заздалегідь комісію за місцем розташування землі, такі землі переходили в державне розпорядження. Існувала також можливість передання вилучених земель через земельні комісії на певний термін мало- або безземельним селянам за визначену плату. Якщо землі, призначені для власного користування, з певних причин не оброблялися, землевласника штрафували на суму від 200 до 500 корон за кожний необроблений гектар. Особа, яка приховувала від держави придатні для сільського господарства землі, не повідомивши про них у відповідні органи, каралася арештом на термін від одного до шести місяців або грошовим штрафом у розмірі від 100 до 50000 корон (залежно від обсягу приховуваних земельних ділянок). 
Оскільки тривала польсько-українська війна, то від повітових комісарів секретаріат у земельних справах вимагав забезпечити суворий контроль над вивезенням зерна за межі повіту, надання дозволів на транспортування продуктів харчування в обмеженій кількості у найнагальніших випадках. Так само встановлювався контроль за засіванням полів весною та збереженням поголів'я худоби в селах [7, с. 186].

До земельної комісії надійшли законопроекти Л. Бачинського, С. Даниловича, А. Онищука, I. Поповича. Найрадикальнішим був законопроект соціал-демократа В. Темницького, який передбачав усуспільнення всіх засобів виробництва та колективне господарювання. Окремі пропозиції подали о. С. Онишкевич та єпископ УГКЦ Григорій Хомишин, які виступали проти конфіскації земель і ратували за вільний земельний ринок [13, с. 3]. Політики лівого спрямування натомість закликали взяти за основу Земельний закон УНР. Загалом, гострі дебати велися навколо допустимих величин земельних ділянок, форми і розмірів відшкодування колишнім землевласникам [7, с. 187].

Під час обговорення земельної реформи в ЗУНР лунали пропозиції недопустимості насильної реквізиції зерна, проведення комасації (ліквідації черезсмужжя). В комісії, яка обговорювала проект реформи, було розуміння того, що селяни не здатні викупити землю, оскільки не мають грошей. Тому пропонувалося конфісковувати землю у великих власників і роздавати їі бідним селянам. Це для частини членів комісії вважалося не зовсім справедливим кроком, до того ж не відповідало правовій традиції. Все ж компромісу було досягнуто, і члени комісії погодилися з конфіскацією землі в тих, хто володів нею понад норму, одержавлення лісів, передачу пасовищ у розпорядження сільських громад.

Секретар внутрішніх справ Іван Макух пропонував опублікувати наявні проекти реформ в ЗУНР (насамперед проекти С. Даниловича і Л. Бачинського) разом із земельним законом УНР, щоб селяни могли їх порівняти. Сам Макух мав зауваження до всіх законопроектів, до яких не прислухалися [7, с. 180]. На мою думку, пропозиції такого характеру були популістськими, тим більше, що про правову грамотність тогочасних селян говорити не доводиться. 3 часом почало з'являтися усвідомлення, що земельна реформа може затягнутися в часі, оскільки все передбачити і реалізувати на практиці було непросто. Крім того, нагальною вважалася потреба завершити війну з поляками, адже реформування земельних відносин у період ведення бойових дій ускладнювало будь-які навіть найкращі починання.

Законопроект Лева Бачинського (1872-1930) передбачав розподіл великої земельної власності й наділення ділянками лише тих, хто на землі працював (трудова норма розподілу землі). Стосовно розмірів, то передбачалося наділяти такою кількості землі, яку був здатний обробити господар разом зі своєю сім’єю. Л. Бачинський пропонував передавати землю у приватну власність із правом передання іï у спадок. Він відкидав можливість передання землі у спільну власність громади (як це зробили на Наддніпрянщині), оскільки галицькому селянину був притаманний індивідуалізм у світогляді [20, с. 18].

Законопроект адвоката Северина Даниловича (1861-1942) дещо різнився від пропозицій Л. Бачинського, зокрема створенням народного земельного фонду для господарювання громадою. Таким чином, радикал С. Данилович 
був прихильником соціалізації землі. Відшкодування великим землевласникам він пропонував встановити в розмірі, еквівалентному ціні землі в Галичині напередодні Першої світової війни. Верхня межа землеволодіння, яке підлягало вивласненню, становила від 50 до 100 моргів (один морг рівний 0,57 га). Детально не йшлося про спосіб передання землі селянам. Після створення земельного фонду ним мали розпоряджатися селянські громадські ради, покликані організувати господарювання [13, с. 4].

Після попередніх обговорень 7 березня 1919 р. земельна комісія УНРади прийняла проект Закону «Основи земельної реформи», який підлягав доопрацюванню. Доопрацьовувати документ мав спеціальний комітет: Л. Бачинський (голова), М. Королюк, Р. Перфецький, Л. Петрушевич, І. Попович, о. П. Філяс. Вдосконалений законопроект комітет зобов'язувався до 24 березня 1919 р. представити земельній комісії на подальший розгляд [7, с. 187].

За тиждень після такого представлення, 1 квітня 1919 р., проект земельного закону перед УНРадою реферував юрист Роман Перфецький, котрий зазначив: «Вся вивласнена земля становить земельний фонд західної області УНР. Тим фондом - до часу розділу між управнених - орудують під наглядом правительства обласна і повітові та громадські земельні комісії». Стосовно важливості закону доповідач зазначив, що «зреалізуються вікові мрії нашого народа. Він дістане в свої руки верстат своєї праці та стане хазяїном у своїй хаті на своїм полі» [7, с. 238].

Оскільки в УНРади виникли певні доповнення, 11 квітня 1919 р. iї представників було ознайомлено зі змінами до законопроекту, зокрема передбачалися відшкодування за вилучену землю (але не викуп). Втім форму відшкодування мав визначити майбутній Сейм ЗОУНР. Майбутній український сейм повинен був встановити розмір ціни продажу землі і вирішити, як наділятимуть землею нових власників - за певну платню чи безкоштовно.

Друга зміна полягала в чіткішому визначенні компетенції обласних і повітових земельних комісій. Саме в такому вигляді Земельний закон і був схвалений 14 квітня 1919 р. Згідно з його положеннями ліквідовувалося велике державне і монастирське землеволодіння - необроблювані землі і ті, що перевищували встановлені розміри. У преамбулі Закону йшлося: «Вивласнюються всі двірські обшари, всі добра монастирські, єпископські, еракціональні, фундаційні, всі землі, набуті під час спекуляції, як також всі землі, котрі перевищувати будуть найвищу границю індивідуального посідання землі» [11, с. 109].

Втім, у цьому законі не зазначалося, чи в процесі конфіскації передбачене відшкодування попереднім власникам земельних володінь. Під конфіскацію без відшкодування підпадали земельні угіддя, власники яких зі зброєю в руках виступили проти української державності. Крім того, якщо в судовому порядку було доведено набуття земельної ділянки незаконним шляхом, така ділянка також вилучалася без жодної компенсації [16]. Конфіскації підлягав також сільськогосподарський інвентар, який належав до конфіскованого наділу. Водночас не можна було вилучати одяг і предмети домашнього вжитку (посуд, постіль і тому подібне).

3 вилучених земель створювався земельний фонд ЗОУНР, яким під контролем уряду мали право розпоряджатися повітові та обласні органи влади. Піс- 
ля завершення війни з поляками передбачалося організувати поділ землі між мало- і безземельними селянами, ветеранами Української Галицької Армії (УГА), вдовами і сиротами, чоловіки / батьки яких загнули на фронті. Зауважу, що лунали побоювання щодо того, що вояки УГА після того, як довідаються про поділ колишньої панської землі, залишать армію і повернуться додому. Тому розподіл землі відкладався до завершення польсько-української війни і повернення вояків УГА додому. Дезертири і особи, які ухилялися від служби в УГА, не могли претендувати на земельний наділ. Не володіли правом на землю й громадяни іноземних держав.

Стосовно розмірів земельних наділів не було єдиної думки - дискутували про обсяги від 30 до 100 моргів. Однак ця норма в будь-якому випадку була більшою від розміру середняцького сільського господарства в Галичині до Першої світової війни, яка становила 15-20 моргів [3, с. 140]. Як і в колишньому австрійському законодавстві, самовільне захоплення земель каралося штрафом (до 10 тисяч корон) або навіть арештом (терміном на 6 місяців) [7, с. 10].

Наведені вище положення Земельного закону від 14 квітня 1919 р. (опублікований лише 8 травня 1919 р. в газеті «Республіка») мали низку недоліків, головний із яких, на мою думку, полягав у наділенні землею лише селян, тоді як інші верстви населення ігнорувалися. Такий підхід зменшував соціальну підтримку керівництва ЗУНР. Так само не до кінця був продуманий захист громадян від втрати земельного наділу.

Заклики до переділу землі зачіпали і церкву, як значного землевласника в Галичині, що також не додавало підтримки таким ініціативам. Затягування з реалізацією реформи спричинило самочинні поділи землі без санкції уряду й наростання соціальної напруги. Цією інформацією перейнявся навіть керівник Директорії УНР Симон Петлюра, який у листі до Державного секретаріату зазначав: «Соціальні реформи, а особливо в земельному питанні, а також припинення процесів відшкодування поміщицьких збитків, які обурюють галицьке селянство і настроюють його проти влади, мусять бути розв’язані позитивно в першу чергу. Кожний день зволікання справи неминуче веде до катастрофи. Прошу звернути на це увагу і вжити відповідних заходів, продиктованих державною мудрістю і передбаченням неминучих конфліктів в житті населення Західної України» [18, с. 117].

Випадків стихійного і санкціонованого владою перерозподілу землі було порівняно менше, ніж на Наддніпрянській Україні. Щоправда, в Галичині вони також іноді траплялися. В низці повітів ЗУНР, зокрема в Яворівському, Бродівському, Косівському та інших, таки розпочався стихійний перерозподіл земельної власності. Селяни збиралися на імпровізовані наради, де вирішували кому і скільки виділити землі. У згаданому Яворівському повіті було вирішено виділяти по 15 моргів землі воякам УГА, а іншим українським селянам - по 4 морги. Інколи до перерозподілів долучалися і військові, які перебували в тій місцевості [5, с. 24].

Загалом дослідники (історики і історики права) значно позитивніше оцінюють Земельний закон ЗУНР, порівняно із Земельним законом УНР. Земельна реформа в ЗУНР мала соціальний характер і західноєвропейську спрямованість. Порівнюючи аграрні реформи в Галичині і на Наддніпрянщині, історик Ярослав Грицак 
слушно зауважив: «Приклад ЗУНР наочно демонстрував переваги австрійської правової школи над російським правовим нігілізмом, в атмосфері якого виросли східноукраїнські політики» [3, с. 140].

Олег Павлишин, досліджуючи підготовку аграрної реформи в ЗОУНР писав: «Політична зрілість керівництва ЗУНР виявилася в стратегічному підході до аграрного питання та не сприйнятті популістських гасел, прагненні розв'язати проблему, не лише забезпечивши інтереси мало- і безземельного населення, але й створивши умови для ефективного землекористування. Ще однією особливістю галицько-українського революційного досвіду була одностайність різних верств щодо збереження права власності» [17, с. 180]. Втім, захоплення Галичини поляками влітку 1919 р. знівелювало земельну реформу Державного секретаріату ЗУНР, яка залишалася лише на папері.

Отже, влада ЗУНР намагалася уникнути популістського розв'язання земельного питання в Галичині. Державний секретаріат шукав компромісу в складних соціальних обставинах, дотримуючись принципів правового регулювання і поваги до виробленого в галицьких селян почуття приватної власності. Зважений підхід до питання з мало- і безземелля, яке багато років не могла вирішити в краї австрійська влада, ще не означав успішної реалізації аграрної реформи. Земельний закон від 14 квітня 1919 р. не мав завершеного вигляду, бо уникав розв'язання деяких складних питань до зібрання майбутнього Сейму. Втім, реалізації аграрної реформи і становленню нових правовідносин у земельній сфері на селі завадили зовнішньополітичні обставини та припинення існування ЗУНР як незалежної держави.

\section{Jimepamypa}

1. Баран С. За рідну землю. Справа кольонізації. Львів : Накладом видавничої спілки «Діло», 1936. C. 3.

2. Булгаков А. Земельне законодавство у ході визвольних змагань за часів революції 1917-1920 pp. URL: http://dspace.nlu.edu.ua/bitstream/123456789/13479/1/Bulgakov_114-119.pdf.

3. Грицак Я. Нарис історії України: формування модерної української нації XIX - XX ст. Київ : Генеза, 2000. С. 140-141.

4. Дністрянський С. Додаток. Основні законні постанови Західної області Української Народньої Республіки / Цивільне право. Відень: [Накладом автора], 1919. Т. 1. С. 473.

5. Державний архів Львівської області, ф. 274, оп. 1, спр. 30, арк. 24.

6. Енциклопедія українознавства [Перевидання в Україні] / Земельний Банк Гіпотечний. Львів : HTHI 1993. T. 2. С. 783.

7. Західно-Українська Народна Республіка. 1918-1923. Уряди. Постаті / гол. ред. Я. Ісаєвич; упоряд. М. Литвин, І. Патер, І. Соляр. Львів : Інститут украӥнознавства ім. І. Крип'якевича НАН України, 2009. С. 5, 6, 10, 180, 185-187, 238.

8. Західно-Українська Народна Республіка 1918-1923. Документи і матеріали: в 5 т. Відп. ред. О. Карпенко. Івано-Франківськ : Лілея НВ, 2001. Т. 1. С. 336.

9. Західно-Українська Народна Республіка 1918-1923. Документи і матеріали: в 5 т. Відп. ред. О. Карпенко. Івано-Франківськ : Лілея НВ, 2001. Т. 2. С. 181.

10. Качараба С., Рожик М. Українська еміграція. Еміграційний рух зі Східної Галичини та Північної Буковини в 1890-1914 рр. Львів, 1995. С. 10.

11. Кондратюк К. Новітня історія України. 1914-1945 рр. Вид. 2-ге доповн. Львів : ЛНУ ім. I. Франка, 2018. С. 109.

12. Корнієнко П.С. Трансформації земельних відносин в українському селі (IX - початок XXI ст.). Порівняльний аналіз. Тернопіль, 2015. С. 233-234. 
13. Малик Я. Державна аграрна політика Західноукраїнської Народної Республіки // Науковий вісник. 2008. Вип. 2. Демократичне врядування. С. 1, 3, 4.

14. Мукосій К. Земельна реформа в контексті внутрішньої політики Української Народної Ради. URL: http://dspace.tneu.edu.ua/bitstream/316497/31201/1/250.PDF.

15. Нараївський Є. Правовий порадник. Популярний збірник карного, иивільного й адміністраційного права. Коломия : Рекорд, 1932. С. 211, 254. (830 с.)

16. Основи земельної реформи. URL: http://www.hai-nyzhnyk.in.ua/doc2/1919\% 20(03)\% 20(07). zem.\% 20reforma.php.

17. Павлишин О. Підготовка аграрної реформи в 30 УНР. Україна: культурна спадщина, національна свідомість, державність. Вип. 6. Львів, 2000. С. 180.

18. Тимченко Р. Земельна реформа ЗУНР (ЗОУНР) 1919 р. Український історичний збірник. Вип. 15. 2012. С. 108, 110, 116, 117.

19. Ухач В.З. «Найголовніша жура нашої власти»: земельна реформа у державотворенні ЗУНР (ЗОУНР. Тенденції і перспективи розвитку інститутів права та держави. Київ : ApmEк, 2018. C. 285-288.

20. Центральний державний архів України у м. Львові, ф. 361 (Крушельницький Антін (1878-1931), письменник, журналіст, літературний критик), оп. 1, спр. 148, арк. 18.

21. Allgemeines bьrgerliches Gesetzbuch fbr die deutschen Erblдnder der Oesterreichischen Monarchie. Teil 1-3. Wien : k. k. Hof- und Staats-Druckerey, 1811. Teil 2. S. 56, 59, 93.

\section{Анотація}

Лесик О. В. Розвиток земельних правовідносин у Західно-Українській Народній Республіці (1918-1919 рр.). - Стаття.

Сучасні умови реформування правового регулювання земельних відносин спрямовані на забезпечення раціонального й ефективного використання земельних ресурсів, як важливого чинника побудови сильної та незалежної держави. Реформування земельного законодавства України не можливе без вивчення і врахування історичного досвіду становлення й розвитку правового регулювання земельних відносин на українських землях від найдавніших часів і до сьогодні.

В 1918 р. Австро-Угорська монархія фактично припинила існувати, а на її руїнах виникли нові національні держави, з-поміж яких і Західно-Українська Народна Республіка. Цього ж року українські військові формування встановили контроль над найважливішими стратегічними об'єктами Львова та Східної Галичини. Ця подія увійшла в історію як «листопадовий чин». У зв'язку з цим особливий інтерес викликає історико-правовий аналіз розвитку земельних правовідносин в Західно-Українській Народній Республіці (1918-1919 рр.).

У статті проаналізовано особливості розвитку земельних правовідносин в Західно-Українській Народній Республіці (1918-1919 рр.). Зазначено, що влада Західно-Української Народної Республіки намагалася уникнути популістського розв'язання земельного питання в Галичині. Державний секретаріат шукав компромісу в складних соціальних обставинах, дотримуючись принципів правового регулювання і поваги до виробленого в галицьких селян почуття приватної власності. Зважений підхід до питання з мало- і безземеллям, яке багато років не могла вирішити в краї австрійська влада, ще не означав успішної реалізації аграрної реформи.

Зазначено про земельну реформу в Західно-Українській Народній Республіці, яка мала соціальний характер і західноєвропейську спрямованість. Земельний закон від 14 квітня 1919 р. не мав завершеного вигляду, бо уникав розв'язання деяких складних питань до зібрання майбутнього Сейму. Показано, що реалізації аграрної реформи і становленню нових правовідносин у земельній сфері українських селах завадили зовнішньополітичні обставини та припинення існування Західно-Української Народної Республіки як незалежної держави.

Ключові слова: земля, правовідносини, правове регулювання, законодавство, республіка. 


\section{Summary}

Lesyk O. V. Development of land legal relations in the Western Ukrainian People's Republic (1918-1919). - Article.

Modern conditions for reforming the legal regulation of land relations are aimed at ensuring the rational and efficient use of land resources as an important factor in building a strong and independent state. Reforming the land legislation of Ukraine is impossible without studying and taking into account the historical experience of formation and development of legal regulation of land relations in the Ukrainian lands from ancient times to the present day. In 1918, the Austro-Hungarian monarchy virtually ceased to exist, and new nation-states emerged on its ruins, including the Western Ukrainian People's Republic.

In the same year, Ukrainian military units established control over the most important strategic sites in Lviv and Eastern Galicia in general. This event went down in history as the "November Act". In this regard, of particular interest is the historical and legal analysis of the development of land relations in the Western Ukrainian People's Republic (1918-1919). The article analyzes the peculiarities of the development of land relations in the Western Ukrainian People's Republic (1918-1919). It is noted that the authorities of the Western Ukrainian People's Republic tried to avoid a populist solution to the land issue in Galicia. The Secretariat of State sought a compromise in difficult social circumstances, adhering to the principles of legal regulation and respect for the sense of private property developed by Galician peasants.

A balanced approach to the issue of scarce and landlessness, which for many years could not be solved by the Austrian authorities in the region, but did not mean the successful implementation of agrarian reform. The land reform in the Western Ukrainian People's Republic, which had a social character and a Western European orientation, is mentioned.

The Land Law of April 14, 1919, was not finalized because it avoided resolving some difficult issues before the future Seimas convened. It is shown that the implementation of agrarian reform and the formation of new legal relations in the land sphere in Ukrainian villages were hindered by foreign policy circumstances and the cessation of the existence of the Western Ukrainian People's Republic as an independent state.

Key words: land, legal relations, legal regulation, legislation, republic. 